\title{
ZDRAVA LJUBAV KAO PREDUVJET ZDRAVLJA
}

\author{
Ivan Vukoja ${ }^{1 *}$, Rajka Šimunović ${ }^{1}$, Ana Vukoja ${ }^{1}$, Branimir Rančić², Lucija Bagarić Krakan ${ }^{1}$ \\ ${ }^{1}$ Udruga narodnog zdravlja Andrija Štampar, Rockefellerova 4, 10000 Zagreb, Hrvatska \\ ${ }^{2}$ Dom zdravlja Gadžin Han, Miloša Obilića bb, 18240 Gadžin Han, Srbija
}

\begin{abstract}
Sažetak
Ne postoji jedinstvena definicija ljubavi, ali je nedvojbeno da je zdrava ljubav preduvjet fizičkog, psihičkog, duhovnog i socijalnog blagostanja, a samim time i preduvjet cjelokupnog zdravlja. S logoterapeutskog stajališta postoje tri dimenzije ljubavi. Fizička komponenta predstavlja nagonsku komponentu koja brine o produženju ljudske vrste, psihička komponenta je prisutna u fazi zaljubljenosti u kojoj vidimo bitne odlike i ljudske osobe te se približavamo psihičkoj unutrašnjosti osobe u koju smo zaljubljeni. Ljubav se u potpunosti očituje kroz duhovnu dimenziju koja svjesno uključuje tjelesnu i psihičku komponentu, te se kroz duhovnu dimenziji odlučujemo za osobu u svim njenim dimenzijama radi njezine jedinstvenosti. Pošto je logoterapijska premisa da je duhovna komponenta čovjeka neovisna o bolestima te nužno zdrava, tako je i ljubav doživljena kroz duhovnu dimenziju nužno zdrava. Duhovna dimenzija ljubavi je svevremenska i neovisna je o svim promjenama fizičke i psihičke komponente koje se protokom vremena događaju (Vukoja i sur 2015). Logoterapija ističe pet izrazitih opasnosti za ljubav. Ubrzan životni tempo ističe pitanje gubitka životne orijentacije i smisla uz stvaranje osjećaja egzistencijalnopg vakuuma, uz zatvoren krug tempa kao uzročnika ovisnosti i neuspjela pokušaja samoizlječenja. Pretjerana seksualiziranost je neuspio pokušaj ostvarivanja ljubavi kroz samo fizičku dimenziju što dovodi do psihičke patnje i izoliranosti duha. Dosada je jedan od vodećih faktora u razvoju psihičkih smetnji i destrukcije ljubavi, jer čovjek u besmislu provodi vrijeme. Negativističan stav i pretjerano potenciranje negativnog u potpunosti prožimlje čovjeka izravno ugrožavajući sve njegove dimenzije. Manipulirana nemoć nastaje produbljivanjem egzistencijalnog vakuuma u potpun gubitak osjećaja za vrijednosti općenito. Frankl navodi da je ljubav je najvažniji element za očuvanje ljudskog života i najvažniji element za očuvanje zdravlja u psihohigijenskom smislu (podrazumijevajući trodimenzionalnost ljudske osobe).
\end{abstract}

Ključne riječi: ljubav, logoterapija, duhovna dimenzija ljubavi, egzistencijalni vakuum, manipulirana nemoć, seksualiziranost

\begin{abstract}
There is no single definition of love, but it is certain that a healthy love prerequisite physical, mental, spiritual and social well-being, and therefore precondition of overall health. With logotherapeutic standpoint there are three dimensions of love. The physical component is an innate component that takes care of the extension of the human species, psychological component is present in the phase of falling in love in which we see the essential features of the human person and are approaching the psychological interior of the people in that we love. Love is fully reflected in the spiritual dimension that consciously includes physical and psychological component, and the spiritual dimension decides for a person in all its dimensions because of his/her uniqueness. Logotherapeutic premise is that the spiritual component of human is independent of disease and necessarily healthy, so it is the love experienced with spiritual dimension necessarily healthy. The spiritual dimension of love is timeless and independent of any changes in the physical and psychological components that can occur over time. Logotherapy points out five distinct dangers for love. A fast lifestyle stresses the question of loss of life orientation and the creation of a sense of meaning existence vacuum, with closed circuit tempo as the cause of addiction and failed
\end{abstract}


attempts of self-healing. Excessive sexuality is a failed attempt to make love through a physical dimension, which leads to mental suffering and isolation of the spirit. Boredom is one of the leading factors in the development of mental disturbances and destruction of love, because of spending time in absurdity. Negativistic attitude and over-emphasizing the negative fully impregnates man directly threatening all its dimensions. Manipulated impotence occurs deepening existential vacuum in the complete loss of the sense of values generally. Frankl said that love is the most important element for the preservation of human life and the most important element for health in psychohygienic terms (assuming the three-dimensionality of the human person).

\section{Uvod}

Gotovo svaki treći brak u Republici Hrvatskoj završava razvodom, a u razvijenim zapadnim zemljama godišnji broj sklopljenih brakova i razvoda praktički je jednak. Kad se tomu pridoda i određeni broj brakova u kojima manjka ljubavi, ali koji se iz inih razloga održavaju, možemo reći da je nedostatak ljubavi, prevladavajuća patološka ljubav ili pak sindrom slomljenog srca jedan od glavnih razloga psihosocijalnih, a posljedično tome i fizičkih oboljenja. Najnovija istraživanja (Yaméogo i sur 2015) jasno povezuju određena kardio i cerebrovaskularna te maligna oboljenja s depresijom, dugotrajnom anksioznošću i stresom (Ho i sur 2015) u čijoj podlozi zasigurno i jedan od faktora jest određena devijacija ljubavi. Poseban logoterapijski pojam koji sve dovodi u svezu jest noopsihomatika, princip koji sitiče da je imunološki sustav izravno ovisan o emocionalnom stanju, a emocionalno stanje je ovisno o ispunjenju smisla. Sve veći broj mladih ljudi oboljeva od bolesti koje su se povezivale sa starijom životnom dobi što bi zasigurno trebao biti razlog za preispitivanje zapadnjačkog načina života u kojemu su sve ljudske, ali i više vrijednosti, stavljene pod upitnik. U neprestanom jurcanju za novim izazovima čovjek posve zaboravlja na sebe, a čovjek koji ne uočava sebe ne mari ni za druge. S druge strane, čovjek koji je zaboravivši na sve humane norme postao sam sebi svrha postojanja, ne mari za druge jer pokušava besmislom ispuniti prazninu u sebi samome. Djeca rođena u nedostatku ljubavi, kao i djeca iz razorenih obitelji, ali i djeca iz netradiocionalnih zajednica jednako kao i zapostavljana djeca u tradicionalnim obiteljima zasigurno imaju određen stupanj psihosomatskih ali i socijalnih problema (Cohen i sur 2015). Sve veći broj djece oboljele od sindroma smanjenje pozornosti, sve veći broj sucida i ovisnosti u tinejdžerskoj dobi, kao i sve veći broj odlazaka maloljetnika psiholozima nisu produkt razvoja svijeta, već najvjerojatnije sustavnog zanemarivanja ljubavi i tradicionalnih vrednota (Horan i Widom 2015). Prava istraživanja na tu temu vrlo vjerojatno nikada neće biti provedena. Za očekivati je u skoroj budućnosti sve veću „liberalizaciju“ braka ili životnog zajedništva kao dodatnog čimbenika u destabilizaciji društva kroz dekriminalizaciju pedofilije i demistifikaciju poligamije, zoofilije ili drugih devijatnih moralnih i društvenih obrazaca. Zapadna kultura i zapadnjaci su odbacivši istinsku ljubav, ,a prigrlivši kao glavne idole sebe same, svoj materijalizam, svoj individualizam, hedonizam, konzumizam, prazni racionalizam i sve ostale nastranosti i sljepoće, počeli metaforički i doslovno ubijati sve što su bili i što jesu“" (Tomić 2015). Tendencija obezvrijeđivanja nesebične ljubavi postaje mantra zapadnog života jer je za vlastiti besmisao potrebno naći opravdanje koje se pronalazi tek kada se zatire nesebična ljubav kao osnova socijalno i psihofizički stabilne tradicionalne obitelji. S druge strane, uništavanje tradicionalne obitelji ekonomsko je pitanje u kojoj prvenstveno treba zatrti ekonomski stabilnu i donekle nezavisnu zajednicu u mnoštvo zavisnih pojedinaca. Zavisni su pojedinci psihosocijalno ranjeni te pokušavaju ispuniti prazninu nastalu destrukcijom obitelji prolaznim životnim radostima potičući vlastiti konzumerizam i ispraznost, odnosno u egzistencijalni vakuum.

\section{Logoterapija}

Logoterapija je vrsta psihoterapije koja se bavi proučavanjem smisla ljudske egzistencije i pronalaženjem tehnika kojima se ljudima može pomoći da otkriju vlastiti smisao života. Osnivač logoterapije je Viktor Frankl (1905. - 1997.), 
bečki neuropsihijatar i pripadnik Treće bečke škole psihoterapije koji je na osnovu vlastitih iskustava $\mathrm{i}$ promišljanja u koncentracijskom logoru utemeljio logoterapiju. Osnova koju logoterapija promiče jest jedinstvenost psihičke, fizičke i duhovne dimenzije čovjeka, u kojemu je duhovna dimenzija neoboljiva. Duševna i duhovna instanca su međusobno povezane i neraskidive te ovise jedna o drugoj, dok nasljeđe, kultura, utjecaj okoline, podrijetlo, obrazovanje i brojni drugi faktori određuju jedinstvenost i neponovljivost osobe, njezina/njegova načina života (Bagarić Krakan 2014). Svaki pojedinac ima određenu zadaću za njega samoga, koja je samo njemu dana. Jedinstvenost te zadaće očituje se u njezinom otkriću, a ne datosti, stoga pojedinac neprestano traga za smislom u svakoj pojedinoj životnoj situaciji, pa tako i smislom vlastita života (Bagarić Krakan 2014). Životni smisao je jedinstven svakom čovjeku i njegovom životu. Otkriti novi smisao života ne znači da je onaj prethodni bio pogrešan. To je vrlo bitna činjenica čijim usvajanjem štitimo sebe od osećaja diskontiuteta vlastite prošlosti i različitih načina na koje smo sebe u njoj doživljavali (Miletić 2011). Svaka osoba ima slobodan izbor, slobodu od nečega ili slobodu za nešto. Primjerice, odricanje čovjeku uskraćuje trenutnu ugodu ili zadovoljstvo ali empatijski usmjereno odricanje prema drugom čovjeku će ga ispuniti i dati konačni smisao učinjenoj gesti (Miletić 2011). Glavni uzrok brojnih bolesti današnjice Frankl vidi u pomanjkanju svrhe i smisla života, što uzrokuje duševni nemir, "besciljnosti", "besmisla" i "praznine" (noogene neuroze). Logoterapija uči kako u životu postoji objektivni i opći smisao koji vraća ljudima vjeru u život i budi smisao za odgovornost. Budući da je čovjek slobodno i odgovorno biće, Frankl ne priznaje nikakav determinizam koji bi upravljao njegovom sudbinom. Čovjek je kovač svoje sreće i sposoban je otkrivati vrednote života, u čemu ga vodi savjest, koja je njegov "organ smisla" (Puljić 2005). Logoterapija govori o elementarnoj ljudskoj potrebi autotranscendencije, nadrastanja samog sebe, radi nečega ili nekoga tko će životu dati smisao. Često se ljudi razočarano ispituju, u što su potrošili dosadašnji život i da li je to zaista sve što bi trebali doživjeti. Frankl je naglašavao da ne postoji „kolektivna krivnja niti kolektivna zasluga“ jer odgovornost za naše osobno ponašanje nosimo mi sami. Promatrajući i istražujući ljudsku psihu Frankl je otkrio da je najmasovnija neuroza današnjeg vremena noogena neuroza. Riječ je o stanju u kojem čovjek ne vidi nikakvog smisla svome životu pa prema tome živi u egzistencijalnom vakuumu. Simptomi tog vakuuma jesu nedostatak volje za životom, nedostatak životnog smisla, nedostatak volje da se odraste i preuzme briga za svijet „non future generation“ (Pahljina 2012). Teoriju o logoterapiji Frankl sažima u tri pojma: slobodna volja, volja za smislom i smisao života (Puljić 2005). Depresivno raspoloženje može biti posljedica noogene neuroze ili kao reakcija na različite gubitke u životu (smrt bliske osobe, raspad braka, gubitak službe, tjelesna ozljeda ili bolest i slično). Važno je znati da postoje događaji i životne okolonosti iz prošlosti koji se ne mogu promijeniti, također i naše tjelesno i psihičko zdravlje spada u neizmjenjivu kategoriju. Međutim to što ću sa svime time napraviti, kakav ću stav zauzeti ovisno je isključivo o meni, mogu se doživljavati kao nemoćna žrtva, mogu izabrati ulogu osobe kojoj se cijeli život događa krivnja, ali se mogu i odmaknuti od traumatske situacije i pogledati sebe iz distance. Mogu potražiti što se u mojoj ličnosti skriva, koji talenti nisu iskorišteni, što me veseli, što bih dobrog mogli napraviti za svijet u kojem živimo (Pahljina 2012).

\section{Logoterapijski pogled na ljubav}

\section{Dimenzije ljubavi}

S obzirom da logoterapija gleda čovjeka kao trodimenzionalno biće u jedinstvu psihofizičke s duhovnom dimenzijom na isti načine sagleda i ljubav. Stoga izdvajamo tri logoterapijske dimenzije ljubavi.

Fizička dimenzija ljubavi najjednostavnija je i najosnovnija dimenzija ljubavi. Na biološkom nivou je prisutna nagonska komponenta koja brine o zadovoljenju osnovnim nagona među kojima je i nagon za produženje ljudske vrste. U tijelu osjećamo podražaje i promjene povezane s našim nagonima, hormonske i neurotransmiterske prilagodbe koje organizam pripremaju za zadovoljenje osnovnih funkcija. Pošto je fizič- 
ka dimenzija osnovna i u velikom svom dijelu nesvjesna, ne predstavlja osobni odnos u užem smislu. Kroz fizičku dimenziju nije moguće niti ostvariti bilo kakav dublji odnos, ali je zdrava fizička dimenzija nužna u potpomaganju i razvoju te stabilizaciji ostalih dimenzija (Frankl 1978, 1980, 1990, 1998, 2010).

Psihička dimenzija ljubavi najizraženija je i pojavljuje se u fazi zaljubljenosti. Osim osnovne fizičke privlačnosti primjećujemo i bitne odlike pertnerske ličnosti, približavamo se njezinoj/ njegovoj psihičkoj unutrašnjosti. Zdrava psihička dimenzija bazira se na kompatibilnosti životnih i svjetonazorskih stavova, zajedničkih interesa i hobija. Zdrava psihička dimenzija preduvjet je za razvoj ljubavi kroz duhovnu dimenziju, ali isto tako nužan je faktor stabilnosti fizičke dimenzije (Frankl 1978, 1980, 1990, 1998, 2010). Duhovna dimenzija ljubavi je svjesna i tjelesne i psihičke, te ih uključuje. Osobu volimo radi nje same, a ne radi njenog vanjskog izgleda ili zajedničkog interesa. $\mathrm{Na}$ duhovnom nivou volimo osobu u svim njenim dimenzijama radi njezine jedinstvenosti, neponovljivosti, dakle njene biti i bez obzira na sve promjene koje će vrijeme donijeti. S obzirom da je duhovna dimenzija konstantna i neoboljiva ona je nužna za održanje ljubavi kroz godine bez obzira na ugroze i mijene kroz koje prolaze fizička i psihička dimenzija. Potpuno zdrava ljubav može se ostvariti isključivo kroz zdravu duhovnu dimenziju. Iz duhovne dimenzije proizlazi vjernost (ako je u ljubav uključena duhovna dimenzija ona postaje neovisna od psihofizičkih dimenzija te prelazi granice prostora i vremena i nastavlja se i nakon smrti voljene osobe), isključivost (da je svaka osoba jedinstvena i da ju ne možemo zamijeniti niti jednom drugom osobom), samonadilaženje (ljubav na prvoj ili drugoj dimenziji može biti i egoistična, a na duhvnoj dimenziji je ona u potpunosti nesebična). Fizička i psihička dimenzija važne su za razvoj ljubavi, ali je duhovna dimenzija zaslužna za njeno održavanje i njenu trajnost, tj. njeno zdravlje. Primjer za to je svaka ljubav koja se održava duž godine unatoč svim intrinzičnim i ekstrinzičnim opasnostima koji neminovno i svakodnevno u kušnju stavljaju psihičku i fizičku dimenziju. Čovjek je biće smisla i biće s vlastitom odgovornošću te upravo zahval- jujući zdravoj duhovnoj dimenziji odlučuje voljeti i odabrati ljubav, prevladavajući sve trenutne ugroze (Frankl 1978, 1980, 1990, 1998, 2010). Pošto je čovjek društveno i socijalno biće, a njegovi osjećaji usmjereni prema drugom biću, također se u logoterapijske dimenzije ljubavi može uvrstiti i četvrta dimenzija prema učenjima Andrije Štampara, a riječ je o socijalnoj. Sva sebična i ljubomorna ljubav predstavlja patološku ljubav, odnosno stanje ugroze za ostale dimenzije.

\section{Logoterapijski čovjek i ljubav}

Frankl ističe da je čovjek posve čovjek zapravo tek onda kad se posve posvećuje nekoj drugoj osobi, posve on sam postaje onda kad ne vidi i zaboravlja samog sebe. Iz te tvrdnje nužno proizlazi kako je čovjeku za očuvanje vlastitog duševnog zdravlja potrebno biti usmjeren ka nečemu što je izvan njega samog. Zbog toga je jasno da je ljubav intencionalan akt, jer se za ljubav čovjek odlučuje, ona mu nije nametnuta, nego ju čovjek prihvaća. Jednako kao i smisao, čovjek traži ljubav jer mu je potrebna za pronalazak njegovog specifično humanog u vlastitnoj egzistenciji koja pronalazi ispunjenje u vlastitoj autotranscendenciji. Stoga možemo sa sigurnošću tvrditi da je i ljubav sama samonadrastanje, jer pojedinac svjesno prihvaća različitu individuu radi nje same kako bi upotpunio vlastitu trodimenzionalnost te usmjerio svoju aktivnost prema odredištu kao psihofizičkoj korelaciji i načinu bivanja, odnosno vlastite autotranscendencije. Problem može nastati kod depresivnih struktura ličnosti kod kojih biti usmjeren ka nečemu može prerasti u opsesiju i žrtvovanje, umjesto u autotranscendenciju. Žrtvovanje znači zanemarivanje skrbi za vlastitu osobu te pretjeranu i nepotrebnu brigu za druge, koje to može opterećivati i lako prerasti u patološki odnos. Za razliku od životinja kod kojih želja za ugodom i zadovoljstvom te ispunjavanje nagona predstavlja ispunjenje smisla, kod čovjeka ugoda i zadovoljstvo nisu specifično ljudski osjećaji. Čovjek doživljava smisao nevezano sa zadovoljstvom jer živi u duhovnoj dimenziji. Nije nužno da nešto radimo isključivo iz zadovoljstva već možemo raditi i u suprotnosti sa našim zadovoljstvom ako je to radi ispun- 
jenja smisla. Ugoda i zadovoljstvo nisu primarni pokretači ponašanja nego je to isključivo postojanje smislenog cilja. Primjerice, odricanje čovjeku uskraćuje trenutnu ugodu ili zadovoljstvo, ali empatijski usmjereno odricanje prema drugom čovjeku će ga ispuniti i dati konačni smisao učinjenoj gesti. Ukoliko je čovjekova pažnja usmjerena na neki smisleni cilj, nužna nuspojava je zadovoljstvo. Ako netko radi nešto smisleno radi postizanja sreće stvara se isprazni circulus viciosum egzistencijalnog vakuuma. Zadovoljstvo ne može biti glavni cilj nego samo nuspojava postizanja glavnog cilja. Kao biće koje odlučuje, čovjek ,neprestano odlučuje što će biti on sam u slijedećem trenutku“, odluka koju donese ima posljedičan utjecaj na njegovu osobnost što ga čini suodgovornim za sebe. Iz tog razloga u ljubavi je nužno učiti i naučiti se odricati (Frankl 1978, 1980, 1990, 1998, 2010).

\section{Problemi u ljubavi}

S logoterapijskog aspekta 5 je najvećih problema s kojima se ljubav susreće, a sve ih je moguće prevenirati. Prvenstveno problem predstavlja vezivanje $u$ emocionalno nestabilnom i nerazvijenom razdoblju u kojem mnogi patološki odnosi prerastaju u nezdravu ljubav i postaju izvor kasnijih frustracija jer se osobe vežu dok nisu u potpunosti psihofizički razvijene i stabilnog duha. Zatim vezivanje uz prolazne vrijednosti poput novca, utjecaja, nasljeđa, spolnih odnosa i slično, koji predstavljaju prolazne i krive vrijednosti na kojima nije moguće graditi buduće zdrave odnose i koji nikada ne mogu izrasti u zdravu ljubav. Potom su tu nespojivi kompromisi. Prevelike različitosti i pokušaj njihova pomirenja neprincipjelnim i nespojivim kompromisima rezultiraju nezadovoljstvom i frustracijom u oba partnera što naposlijetku neminovno dovodi do bolnog i burnog razlaza. Bitan je čimbenik i strah od samoće. Patološki strah od samoće tjera čovjeka da se zadovolji neadekavatnim izborom koji mu je u trenutku odabira prihvatljivija opcija od samoće. Kasnije će neadekvatan izbor rezultirati nespojivim kompromisima i patološkim odnosima praćenim emocionalnom nestabilnosti. Naposlijetku velik predstavlja rigidnost. Plastičnost odnosa i odupiranje partnerovim mijenama pred- stavlja problem jer odbijanjem promjena odbijamo i partnersku osobu. Nužno je imati otvorenu mogućnost za partnerove promjene, vjerovati da se partner može promijeniti i prihvatiti životne promjene te se prilagoditi novonastaloj situaciji. Nijedna osoba ne ostaje zauvijek onakva kakva jest kad smo je upoznali, pa ni mi sami.

Prema Franklu postoje tri glavna preduvjeta za održavanje odnosa, odnosno ljubavi. Potrebno je jasni uočiti cilj koji treba biti zajednički objema osobama u odnosu, oko cilja nisu mogući kompromisi. Oba partnera trebaju donositi poštene $\mathrm{i}$ iskrene te nesebične zaključke koji ne smiju biti na štetu jednog od partnera. Uzajamni odnos nužno je zajedno trenirati, birati zajedničke aktivnosti i vježbati zajedničko donošenje odluka i zaključaka što će blagotvorno djelovati na buduće procese donošenja odluka. Frankl se također posebno osvrće i na konflikte u odnosima, posebno ističući problem sebičnog traženja vlastitog smisla bez obzira na partnera i njegove potrebe te time naglašava i socijalnu dimenziju ljubavi (Frankl 1978, 1980, 1990, 1998, 2010). Osnovne misli o ljubavi po Franklu

Ljubav je najvažniji element za očuvanje ljudskog života i najvažniji element za očuvanje zdravlja u psihohigijenskom smislu (podrazumijevajući trodimenzionalnost ljudske osobe). Frankl prvenstveno vidi ljubav kao "doživljavanje druge osobe u svoj njezinoj jedinstvenosti i neponovljivosti“ te ,kao intencionalni akt" (namjernu aktivnost) usmjeren na nekog ili neštoizvan nas samih.

Frankl ističe ljubav kao troslojni dar. Prvenstveno ističe ljubav kao milost, ljubav ne možemo kupiti, niti ju možemo uzeti, ljubav ne očekuje zahvalnosti, ali ju podrazumjeva. Ljubav ne podrazumjeva očekivanje, ne podrazumjeva ni uzvraćanje. Ljubav ne predstavlja ni pravo, niti dužnost. Ljubav nije dobitak nego dar, ne možemo učiniti ništa protiv toga da budemo nečiji objekt ljubavi, isto tako ne možemo nekoga natjerati da ljubavi uzvrati. Ljubav je namjeran odabir dvije osobe, ali je ona i dar koji se nudi na izbor. Zatim naglašava čarobnu moć ljubavi koja mijenja doživljavanje svijeta ili osoba, zaljubljena osoba vidi u drugome vrijednosti i potencijale kojih možda drugi nisu svjesni. Frankl navodi da ljubav nije slijepa, nego jasnovidna za vrednote, 
na taj način širi mogućnosti drugoga da se razvija u željenom pravcu, obogaćavajući ga. Naposlijetku zagovara čudo ljubavi, jer začeće kao čudo ljubavi nije posebna zasluga čovjeka, ono je dar u kojemu čovjek samo sudjeluje. Kroz dijete i novi naraštaj, ljubav i osoba autotranscendiraju.

\section{Logoterapeutske teze o ljubavi}

Logoterapijsko poimanje ljubavi u bitnome se razlikuje ne samo od općih svjetovnih shvaćanje, nego i od bitnih poimanja drugih psihoterapijskim smjerova. Prema tome, ljubav je prvenstveno stav, a ne osjećaj kako je to uobičajeno misliti. Osjećaj jest zaljubljenost, ali to je samo jedna dimenzija ljubavi. Ljubav je bezuvjetna odluka za otvaranje i proširenje vlastitih granica, da bi prihvatili drugoga u svoj njegovoj različitosti i neponovljivosti. To pak znači da se ne postavljaju uvjeti za ljubav jer je ljubav bezuvjetna. Nužno je konstantno proširivati vlastite granice, kako bismo za drugoga stvorili prostor $\mathrm{u}$ vlastitom svijetu, na taj način sebe obogaćujemo, ali i usrećujemo drugu osobu koja treba doživjeti da ju osoba koja ju pušta u vlastite granice ljubi. Pritom valja paziti da se vlastiti svijet ne preda drugome, nego da ga se u koegzistenciji pusti da se zajednički stvara novi svijet.

Ljubav prema drugome istovremeno je i ljubav prema samome sebi. Ne postoji ljubav koja bi isključivala i ljubav do vlastite osobe, čak i u slučaju jednostrane ljubavi ima ona pozitivan učinak na osobu. Ako ljubimo bližnjega kao samoga sebe, onda moramo ljubiti i sebe kao svoga bližnjega. Zato je autotranscendencija proces koji traje cijeli život, predstavlja rast i razvoj prema nečemu što ima svoju vrijednost i veće je od poimanja vlastite osobe (Frankl 1978, 1980, 1990, 1998, 2010).

Zdrava ljubav podrazumijeva slobodu koju svaka osoba treba kako bi se razvijala i napredovala u svojoj jedinstvenosti, ako netko vene ili kao osoba siromaši potrebno je zapitati se umire li zdrava ljubav i što to činim da moj rast guši drugog pojedinca.

Također je bitno neprestano razvijati sposobnost za ljubav jer je ljubav odlična prevencija svih kolektivnih neuroza, koje su prema Franklu kvazi neuroze, koje predstavljaju paraklinički fenomen jer se kod njih radi o bolesnom duhu vremena (Frankl 1978, 1980, 1990, 1998, 2010). Bolesni duh vremena preko kolektivnog organizma utječe na pojedinca uzrokujući patološke posljedice poput patološkog životni stava ili životno držanje sklono kriznom reagiranju i brzom prijelazu u neurozu (Lukas 2006, 2013). Osoba koja sebe izgrađuje kroz zdravu ljubav zajedno sa svojim partnerom ima potrebnu životnu stabilnost i usmjerenost te zajednički cilj koji preventivno djeluje na podložnost kolektivnim neurozama i njenim simpotmima poput provizornog držanja (odričemo se hedonizma i sebičnosti u korist zejedničkog cilja i odgovornosti), fatalističkog životnog stava (ako smo svjesni da smo se namjerno odlučili za ljubav ne možemo se izvlačiti na frazu da nije moguće uzeti slobodu u svoje ruke jer je i tako sve unaprijed određeno), kolektivističkog mišljenja (ako se odlučimo za zdravu ljubav i vrednote koje predstavlja ne podliježemo pritiscima okoline i kolektivizma mase; to ne znači da ne treba slušati savjete već da svojevoljno u ljubavi biramo osobu koja možda ne zadovoljava kriterije mase ali jest kompatibilna kao životni partner za nas, odnosno ako skupa prepoznajemo vrednote i zastupamo stajališta u koja smo uvjereni) te naposlijetku fanatizma (ljubav je staložena, a fanatizam kao vrhunac kolektivističkog mišljenja nije spojiv sa zdravom ljubavlju, jer fanatik ne samo da uništava samog sebe, nego uništava i sve oko sebe. Prema Franklu, postoje sredstva koja mogu uništiti i najsvetiji čin (Frankl 1978, 1980, 1990, 1998, 2010).

\section{Opasnosti za ljubav}

\section{Ubrzan životni tempo}

Sve ubrzaniji čovjekov ritam života problem je životne orijentacije pojedinca, jer u odsutnosti životne orijentacije ljudi ne znaju zbog čega žive niti zbog čega umiru. Frankl navodi da što čovjek manje prepoznaje vlastiti životni smisao to više ubrzava vlastiti tempo, što pak stvara osjećaj egzistencijalnog vakuuma. U takvim slučajevima tempo dobiva značenje droge, jer ubrzavanjem tempa pokušavamo ispuniti nastali egzistencijalni vakuum. Ubrzani tempo je istovremeno i uzrok bolesti i neuspio pokušaj samoizliječenja 
(Lukas 2006, 2013).

\section{Seksualiziranost}

Egzistencijalni vakuum se pokušava zatomiti pretjeranom seksualnom aktivnošću u kojoj nema više ograda ili tabua. Sve veće devijantnosti $u$ ispoljavanju fizičke dimenzije rezultat su pojednostavljivanja ljubavi na jednu dimenziju (fizičku) što pak dovodi do psihičke i socijalne patnje te naposlijetku izoliranosti duhovne dimenzije čovjeka. Hiperseksualiziranost postaje sama sebi svrha i stil života jer psihički i duhovno oskvrnjeni pojedinci traže nove žrtve kako bi ispunili vlastiti egzistencijalni vakuum. U društvu u kojem je prisutan velik pritisak, čak i mobbing za prisiljeno ponašanje radi postizanja sreće, čovjek se teško oslobađa pritiska čako i ako ide prema nekom smislenom cilju što i u zdravih pojedinaca dodatno stvara i generira podlogu za razvoj krize (Frankl 1998, 2010, Lukas 2006, 2013).

\section{Dosada}

Dosada predstavlja vodeći čimbenik u razvoju psihičkih smetnji kao što su vikend neuroza, neuroza kod odlaska u mirovinu, kriminal i slično. Isto tako, u dosadi je čovjek skloniji devijatnim oblicima ponašanja koji mogu narušiti psihofizički integritet, dovesti do socijalne izolacije te naposlijetu destrukcije ljubavi (Frankl 1998, 2010, Lukas 2006, 2013).

\section{Potenciranje negativnog}

Negativizmu kao u javnosti širokopropagiranom i zastupanom stavu teško se oduprijeti. Preplavljeni promašenim životima i negativizmom ljudi se prepuštaju dekadenciji optimizma u kojemu žive što snažno prožima čovjeka dovodeći prvo do hormonskih i neurotransmiterskih poremećaja na fizičkoj razini, zatim do psihičkih poremećaja poput raznih neuroza, depresija i raznih oblika anksioznosti, do socijalnih poremećaja koji zatvaraju čovjeka u sebe i dodatno pogoršavaju njegovo psihofizičko stanje. Sve navedeno naposlijetku dovodi do izoliranosti i ugroze duha (Frankl 1998, 2010, Lukas 2006, 2013).

\section{Manipulirana nemoć}

Gubitkom egzistencijalnih vrednota izgubio se osjećaj za vrednote općenito što često dovodi do preopterećenosti radi osjećaja da bi morali imati sve što imaju drugi, a dragovoljno odricanje posatje teško, gotovo nemoguće. Ljudi izbjegavaju odgovornost za vlastiti život i za društvo u kome žive, jer nas odgovornost za vlastitu slobodu može dovesti u sukob s očekivanjima okoline i društvom, svojevrstan bullying okoline (Frankl 1998, 2010, Lukas 2006, 2013).

\section{Povezanost ljubavi i zdravlja}

Medicina 21. stoljeća vrlo često simplificira pojedinca na dvije, često puta i na samo jednu dimenziju, pokušavajući krnje liječiti jednu dimenziju. Takovi pokušaji liječena izolirane bolesti ne dovode do ozdravljenja čovjeka, nego samo do njegova zalječenja, što u konačnici postaje trajna ugroza za čovjeka i njegovu trodimenzionalnost. Logoterapijska specifičnost noopsihosomatike naglašava kako sam imunološki sustav čovjeka ovisi o emocionalnom stanju, a emocionalno pak stanje o ispunjenju smisla. Ispunjenje ljudskog smisla nedvojbeno dovodi do zadovoljstva i stabilnosti duhovne razine, čija je pak stabilnost nužna za staloženost osjećaja na duševno-psihičkoj razini što pak utječe na imunološki sustav na tjelesno-fizičkoj razini. Osjećaji nedvojbeno snažno utječu na imunološki sustav tako da kod velikih uzbuđenja češće nastaju oboljenja ili pak kod ekstremnih epidemija ne oboljevaju ka drugom cilju snažno usmjereni pojedinci. Patološka ili razorena ljubav uzrokom je previše boli i premalo životnog zadovoljstva u životu, što pak bitno utječe na imunitet izlažući organizam neprekidnom i trajnom stanju prevelike agitiranosti i nesrazmjernog povišenja stresa. Osjećaj gubitka smisla života nakon razaranja braka jedan je od najstresnijih čimbenika kao i smrt supružnika što doživljavamo kao ugrozu vlastitom postojanju i bitnu ugrozu vlastitom zdravstvenom stanju. Smislena životna zadaća je najbolje preventivno sredstvo u sprječavanju bolesti, kao i najbolje terapeutsko sredstvo u njenom izlječenju. Pomanjkanje smislene i zdrave ljubavi dovodi do pogoršanja emocionalnog stanja i slabljenja imu- 
niteta, a smislena i zdrava ljubav djeluje na stabilnost emocija, duhovno zdravlje i blagostanje što poboljšava zdravlje i produžuje život pojedinca.

\section{Zaključak}

Frankl navodi da je ljubav je najvažniji element za očuvanje ljudskog života i najvažniji element za očuvanje zdravlja u psihohigijenskom smislu (podrazumijevajući trodimenzionalnost ljudske osobe).

\section{Reference}

Bagarić Krakan L, Vukoja I et al (2014) Logotherapeutic approach in clinical practice. ACC vol 53, supl 1.

Cohen JR et al (2015) Interpersonal Risk Profiles for Youth Depression: A Person-Centered, MultiWave, Longitudinal Study. J Abnorm Child Psychol. 43:1415-1426

Ho AK et al (2015) Association of anxiety and depression with hypertension control: a US multidisciplinary group practice observational study. J Hypertens. 33(11):2215-22

Horan JM, Widom CS (2015) Cumulative childhood risk and adult functioning in abused and neglected children grown up. Dev Psychopathol. 27(3):927-41. Frankl V (1978) Zašto se niste ubili? - uvod u logoterapiju. Oko 3 ujutro, Zagreb

Frankl V (1980) Bog podsvijesti - psihoterapija i religija. Oko 3 ujutro, Zagreb

Frankl V (1990) Liječnik i duša. Kršćanska sadašnjost, Zagreb
Frankl V (1998) Patnja zbog besmislena života. Karitativni fond, Đakovo

Frankl V (2010) Čovjekovo traganje za smislom. Planetopija, Zagreb

Lukas E (2006) Duhovna psihologija. Karitativni fond, Đakovo

Lukas E (2013) Što nas u životu pokreće. Svijetla točka, Zagreb

Miletić D (2011) Logoterapija. Akademija uspjeha. http://www.akademijauspeha.com/clanci_svi/ Logoterapija.html. Objavljeno 21 kolovoz 2011

Pahljina C (2012) Što je logoterapija?. Puls pacijenata-glasilo HKMS. 3: 7-11

Puljić Ž (2005) Franklova logoterapija - liječenje smislom. Druš. Istraž. Zagreb. 4-5 (78-79), 885-902 Tomić IM (2015) O europskom Apocalyptu. Tragom istine. http://studenti.dominikanci.hr/index.php/crkva-i-svijet/526-o-europskom-apocalyptu. Objavljeno 09 rujan 2015

Vukoja I i sur (2015) Zdrava ljubav kao preduvjet zdravlja. Kongresna knjiga sažetaka 4. hrvatskog kongresa o prevenciji i rehabilitaciji u psihijatriji s međunarodnim sudjelovanjem.

Yaméogo NV et al (2015) Sleep disorders, anxiety and depressive symptoms and cardiovascular risk among black African hypertensive: cross-sectional study of 414 hypertensive followed as outpatients at the University Hospital of Ouagadougou (Burkina Faso). Pan Afr Med J. 21:115. 